\title{
Storytelling as Promoting Moral Consciousness: Religious Education Teachers' Perspectives
}

\author{
Mahir Shafiq Al-Hawamleh \\ Al Ain University, UAE \\ $\mathrm{Al}$ al-Bayt University, Jordan
}

\begin{abstract}
This study aims at investigating the role of storytelling in promoting students' moral consciousness; as an educational activity that combines religion with storyline. To achieve this aim, an opinion questionnaire was managed to religious education teachers in Irbid, Jordan in the academic year 2018-2019. The study inquired on to what extent storytelling help in learners' internalize moral behavior conduct in light of Islamic ethics and values. The achieved results specify teachers' excessive sureness in the effectiveness of storytelling role in forming moral behavior.
\end{abstract}

Keywords: Storytelling; moral consciousness; religious education teachers.

\section{Introduction}

Unfortunately, moral consciousness in education is an under-researched area despite its apparent connection to beliefs, identity and one's code of practice and behavior. Recently, morality has become more acknowledged internationally as cultures mingle together most at this recent world (Nielsen, 2000). The augmented significance of morality has appeared in post-socialist societies (Heintz, 2006; Varga, 1993). Contemporary world wars and political conflicts have capitalized immorality as midpoint cause.

On the theme of morality, everyone is awarded in light of his/her own creed and belief. In Islam, morality refers to the ethics that make us endowed with 'goodness' and 'happiness' not only in our worldly life, but in heaven as well. Thus, morality accounts for the two worlds, rather than one and this explains why Islam offers believers peace as a finale goal.

United Nations High Commissioner for Refugees (UNHCR) (2006) presented religion as 'belief', 'identity' marker, 'way of life'. In Islam, religion is defined as "a divine law that enables people with intelligence to attain goodness and happiness in this world and the next with their own desire". Rules come from divine revelation; God. If rules come from man, they will be false. This explains 
the underlying argument behind "Superiority lies only in piety" as every sacred belief is produced by God. The word "law" illustrates that having faith means that moralities, ethics, principles need to be carried out as fixed rules. Therefore, morality is more than an idea, but rather a commitment. Goodness and happiness refer to an end of any moral behavior. It is the feeling of goodness and happiness; rather than tedious responsibilities. These responsibilities can be judged in either ways: informative or constructive.

Of course, informative delineations (imminent from God) stop us from making any error. Secondly, in addition to "informative" judgments giving knowledge, the "constructive" judgments laying down rules with regard to the functioning of a human's life are good for man in many respects. Hence, morality is the broad term for the kind of order, law and conduct of organizing the liaison between God and man.

Of course, international ideological hypotheses by Western scholars are mostly steered towards liberal atheist, secular humanist, socialist and Marxist perspectives (Rumbold, 2002). There is an underlying belief behind the openminded education at schools where morality is introverted as opposing to civilization. Nowadays, schools have long been regarded as opportunities for an outstanding nonreligious free future. It may be the case that the goal of learning is to make learners ready to shoulder their own responsibility at studying and at work; rather than imparting personality or ethical views.

In Islam, morality refers to the internalization of spiritual values; and thereby leading to an inner change in behavior (Halstead, 2007). Regarding the Jordanian context, it is considered one of the most religious countries; as religion along with morality is on the educational agenda in Jordan. Thus, education and morality are often perceived as incompatible.

Research argues that inspiring moral consciousness has helpful impact upon the learner. Such belief may be more substantial if it is built on storyline. It may be much worthy to have thoughtful empirical research that demonstrates these prejudgments touching the effect of moral consciousness. All too often, such prejudgments are merely identified without evidences (Ableman, 2000).

In the words of Benjamin Franklin 1787, an influential former USA president, morality is of high significance as:"Only a virtuous people are capable of freedom". Therefore, controlling one's moral conduct is the only way to success. Al-Ghazali (cited in Alavi, 2007), a prominent Islamic scholar, called for education that is based on character and virtue. For him, there are two parts of morality: pure and applied. This explains why, in the Holy Qura'n, there are 783 verses relevant to pure heartily morality; whereas there are 748 verses for practical morality. Such education is driven by students' acceptance of the lesson; to this end they put the lessons into practice. According to Al-Ghazali, moral education is connected with the heart that ends up with good behavior. Similarly, to Hussain (2007), morality lies with the soul of an individual which leads to an ideal character capable of living in a pleasant-sounding society. 
Of course, morality starts with individuals and proceeds to societies. Putnam quoted, in Our Kids: The American Dream in Crisis, pieces of research on the effect of moral consciousness in society. Putnam concluded that morality has not only virtuous influence; nevertheless it has countless weight upon learners' attainment. As a result, when equating moral with immoral learners, moral learners achieve better scores and thereby succeed in their careers. Besides, moral learners have greater affiliations with their families or any other additional activity. This can be attributed to their ethical construction as inclined by moral consciousness which offers them with the apt context that enables them to thrive.

On reflection, religion and moral consciousness interact. In this regard, Sinnott (2001) introduced morality as relevant to what is sacred in a way that advises our relations that make meaning to one's own life. In fact, for Sinnott (2001), morality possibly will or will not comprise world opinions and creed shared by any group. Religion, in contrast, is relevant to the conduct of opinions, habits and creed concerned with certain dogma.

In his pleasurable book, Gottschall (2012) introduced the first cohesive approach of storytelling. Gottschall claimed that stories support us to face varied social difficulties; in a way that prepare listeners/readers for challenging conditions to safeguard their existence. Further, Chowdhury (2016) highlighted the significant role of morality in science curriculum. He compared and contrasted moral education in both Western and Islamic cultures. The author articulated a theoretical outline for the improvement of moral education is schools; while at the same time proposing pedagogical activities.

Employing the up-to-date review in neuroscience, biology, and psychology, Gottschall (2012) explained the role of storytelling in modifying human behavior. Gottschall gave details on the extent of engagement and absorbing in a story is strongly reflected in behavior change. Thus, all listeners/readers present equivalent type of responses regardless to their context. To Gottschall, stories are powerful explicit and implicit tools for changing the world for the better; especially if they are moral, principled and noble that instill values; thereby shaping our behavior. Nevertheless, sometimes stories create superficial and dangerous behaviors that are fueled with treason theories, national myths, deceptive adds or news that are fallacious. For example, Hitler's goals were somewhat driven by a story. Here, the task of the teacher is to invent an expression (coin a phrase) as phrases guide consciousness and thereby changing students' behaviors.

During the course of history, people have considered religion as a pathway to morality. For example, Boyatzis (2005) reported that 95\% of American youth have faith in God. Boyatzis established that half of American youth state they often pray on their own; while $36 \%$ have church groups. Boyatzis highlighted the result of a national survey which indicates that more than half of sixth -totwelfth grade students describe themselves as 'being religious'. The survey 
showed that about $90 \%$ of caretakers wanted their kids to have religious education classes. Moral conscience brings up cognitive principles supported by emotional conditions that empower us to distinguish between what's right and what's wrong (Stan, 2001). As such, the development of moral conscience entails three successive domains; namely: cognitive, affective and motor. Specifically, morality is the internalization the three domains altogether. Religious education teachers are expected to shape learners' cognitive, affective and motor skills. Of course, The Holy Qur'an encompasses plentiful proofs of moral consciousness and their apt behaviors

A large body of research propose storytelling driven curricula as stories form moral education effectively (Alkaaf \& Al-Bulushi, 2017; Setiawati, 2017; Rossano, 2008; Bunanta, 2003). In light of pieces of research proofs, storytelling has a positive effect on education. As such, teachers should at best acknowledge that it supports the development of their learning. Storytelling entails a story that demonstrates joyful tasks that attract wide addressees. It capitalizes top events, famous people, ethical values, cultural traditions (Ellis, 1997; Alvey, 1974). Walter (2016) stressed the role of storytelling as a platform of breaking up students' consciousness. To Walter, teachers can craft stories. He takes this further and says:"If you want a well paid stable career today you do one of two things. You learn to work with computers. Or you learn to tell stories".

From a social reconstructionist perspective, storytelling is associated with educating conscientiously intended formal, cultural, and religious values (Zeichner \& Liston, 1996). Here the teacher is reflective as being concerned with not only the content of the story, but rather with the 'how' to tell it. Basically, the 'effect' of the story on learner's behavior is what really matters. Questions such as: Where do stories drive them? To what action?. A story that focuses on 'integrity' can change learner's life to the better.

Storytelling is a joint formation process. In this regard, Baker and Greene (1977) stated that storytelling does not refer to the demonstration of learn the text by heart but rather to the interface between the teacher and learners. As a matter of fact, stories are role models in the sense that learners learn by example by the act of imitating and simulating of esteemed conduct (Smith, 1989). Stories are informative and loaded with moral lessons in the sense they inspires learners with precious wisdoms on values such as; friendship, thoughtfulness, tolerance and sharing. To this end, stories are crucial in improving the merits education. Such stories are effective when they are meaningful and relevant to learners' lives in a nondirective manner (Yoo, 1997). In this concern, Kelley (2008) capitalized the significant role of storytelling in identifying learners' attitudes, ethics and views. Further, Molenda and Bhavnagri (2009) established the effectiveness of storytelling in supporting cooperation morals such as; assisting others , sharing, taking and giving turns, allocating duties, discussing, directing, transaction, and presenting views.

As an instructional technique, partaking real-life stories shapes and outlines the learning process intentionally. To this end, learners can learn more from 
reflecting upon what they listen to. Generally, people think chronically as they opt to recall facts in a story manner. Here, Archibald (2008) maintained how stories echo people's where events, facts, characters are better recalled in small blocks of a grander story. Listeners construct and organize meaning in light of what they see or hear.

\section{Problem}

Morality has been manipulated and distorted by some immoral actions. Immorality stimulates ethical crises in our region in particular and world at large. Unfortunately, it has become the reason behind intimidating, oppressing and bullying the weaker ones. Religious education teachers have improved the meaning of moral consciousness in order to form their students' moral behavior. In Jordan, parents as well as teachers rely heavily on stories mentioned in our creed; Islam. It is very much expected that Islam feeds these stories. The rhetoric raised by this study examines the role of storytelling as a means to such end.

\section{Aim}

This study aims at investigating the role of storytelling in raising moral consciousness as a means of embodying religious morality segments throughout students' conduct of suitable moral conduct.

\section{Questions}

The present study attempted to answer one major question: what is the effect of storytelling in promoting moral consciousness as perceived by religious education teachers? Then, three sub-questions stemmed out from the major question in order to consider all tentative factors that may affect teachers' perceptions. These questions are as follows:

1. Are there any statistically significant differences on teachers' responses that are associated with their gender?

2. Are there any statistically significant differences on teachers' responses that are associated with their teaching experience?

3. Are there any statistically significant differences on teachers' responses that are associated with their academic qualification?

\section{Method}

The descriptive survey research was selected as the research design of the present study. Here, the study used descriptions and classification, measurement in order to compare and describe responses. Details of the specific aspects of the participants and the instrument are as follows:

\section{The participants}

The settings of this study involved religious education teachers who were selected randomly. Specifically, fifty religious education teachers responded to the opinion questionnaire developed by the researcher. They were randomly selected from twenty-five schools in Irbid district in the academic year 20182019. The sample represented $50 \%+1$ of the targeted school population as it was 49 schools. A symmetrical distribution of gender, academic qualification, and teaching experience was considered. The following Tables demonstrate such symmetrical distribution: 
Table 1. The symmetrical distribution of gender variable

\begin{tabular}{ll}
\hline Gender & Number of religious education teachers \\
\hline Male teachers & 23 \\
Female teachers & 27 \\
Overall & 50 \\
\hline
\end{tabular}

Table 2. The symmetrical distribution of academic qualification variable

\begin{tabular}{ll}
\hline Academic Qualification & Number of religious education teachers \\
\hline Diploma degree & 2 \\
Bachelorettes degree & 39 \\
Master degree & 9 \\
Overall & 50
\end{tabular}

Table 3. The symmetrical distribution of teaching experience variable

\begin{tabular}{ll}
\hline Years of Experience & Number of religious education teachers \\
\hline 1-5 years & 3 \\
More than 5 years & 47 \\
Overall & 50 \\
\hline
\end{tabular}

\section{Instrument:}

To meet the aim of this study, the researcher developed a thirty-item opinion questionnaire that was validated by a jury of university instructors at $\mathrm{Al}$ alBayt University. For reliability, Alpha formula (Cronbach Alpha) was applied to decide the reliability of the questionnaire. The results showed that the score of reliability was 0.91; which was considered suitable for the purpose of the study. The researcher himself distributed the copies of the questionnaire.

\section{Procedures}

In the present study, the aim was investigating the role of storytelling in promoting moral consciousness. First, the researcher selected 50 teachers. He got the number of the teachers from the supervisors in Irbid Directorate of Education. The researcher selected the participants of the study randomly, which characterized $70 \%$ from the population. The researcher himself circulated the opinion questionnaire. In order to have reliability and validity of the responses, the targeted teachers were invited to fill in the questionnaire either at once or later at their convenience. Fortunately, the researcher was able to collect all the distributed copies. Then the data were statistically treated.

Second, means, standard deviations, T- test and one way ANOVA statistics were used for analyzing the obtained data. Based on coding on a scale categories as developed by the researcher, the following was considered in interpreting the results, $80 \%$ and more was considered as 'very good'; $79.9 \%-70 \%$ was seen as 
'good'; 69.9\%-60\% was viewed as 'medium'; $59.9 \%-50 \%$ was considered as 'poor'; and less than $50 \%$ was seen as 'very poor'.

\section{Findings}

The major research question reads as: what is the effect of storytelling in promoting moral consciousness as perceived by religious education teachers? Means, standard deviations, percentages, numbers and rank order were used to find out such effect. This is shown in Table 4:

Table 4. The role of storytelling in promoting moral consciousness

\begin{tabular}{|c|c|c|c|c|c|c|}
\hline $\begin{array}{l}\text { Rank } \\
\text { order }\end{array}$ & No. & $\begin{array}{l}\text { The role of storytelling in promoting } \\
\text { moral consciousness by: }\end{array}$ & Mean & \begin{tabular}{|l|} 
St. \\
Dv.
\end{tabular} & $\%$ & $\begin{array}{l}\text { Impact } \\
\text { degree }\end{array}$ \\
\hline 1 & 30 & Stimulating Islamic moral standards & 4.50 & 0.54 & 90 & $\begin{array}{l}\text { Very } \\
\text { good }\end{array}$ \\
\hline 2 & 4 & $\begin{array}{l}\text { Instilling 'Holy Qur'an' and } \\
\text { 'Prophetic tradition' as sources of } \\
\text { Islamic standards }\end{array}$ & 4.38 & 0.57 & 87.60 & $\begin{array}{l}\text { Very } \\
\text { good }\end{array}$ \\
\hline 3 & 1 & $\begin{array}{l}\text { Distinguishing between 'standard' } \\
\text { and 'opinion' }\end{array}$ & 4.34 & 0.56 & 86.80 & $\begin{array}{l}\text { Very } \\
\text { good }\end{array}$ \\
\hline 4 & 5 & $\begin{array}{l}\text { Capitalizing the need for considering } \\
\text { morality }\end{array}$ & 4.26 & 0.60 & 85.20 & $\begin{array}{l}\text { Very } \\
\text { good }\end{array}$ \\
\hline 5 & 9 & $\begin{array}{l}\text { Realizing that dishonest deeds are } \\
\text { irrelevant to mortality }\end{array}$ & 4.20 & 0.76 & 84.00 & $\begin{array}{l}\text { Very } \\
\text { good }\end{array}$ \\
\hline 6 & 2 & $\begin{array}{l}\text { Encouraging students to intermingle } \\
\text { as moral. }\end{array}$ & 4.16 & 0.71 & 83.20 & $\begin{array}{l}\text { Very } \\
\text { good }\end{array}$ \\
\hline 7 & 24 & $\begin{array}{l}\text { Considering freedom of standard } \\
\text { norms as immoral }\end{array}$ & 4.06 & 0.77 & 81.20 & $\begin{array}{l}\text { Very } \\
\text { good }\end{array}$ \\
\hline 8 & 27 & $\begin{array}{l}\text { Considering illegal deeds as } \\
\text { immoral }\end{array}$ & 4.06 & 0.65 & 81.20 & $\begin{array}{l}\text { Very } \\
\text { good }\end{array}$ \\
\hline 9 & 12 & $\begin{array}{l}\text { Encouraging students to take part in } \\
\text { voluntary acts as being moral }\end{array}$ & 4.06 & 0.77 & 81.20 & $\begin{array}{l}\text { Very } \\
\text { good }\end{array}$ \\
\hline 10 & 14 & $\begin{array}{l}\text { Encourages students to earn money } \\
\text { effortlessly as immoral }\end{array}$ & 4.04 & 0.83 & 80.80 & $\begin{array}{l}\text { Very } \\
\text { good }\end{array}$ \\
\hline 11 & 15 & $\begin{array}{l}\text { Instilling that hurting oneself as } \\
\text { immoral }\end{array}$ & 4.04 & 0.70 & 80.80 & $\begin{array}{l}\text { Very } \\
\text { good }\end{array}$ \\
\hline 12 & 10 & $\begin{array}{l}\text { Realizing that not doing bad things } \\
\text { as moral }\end{array}$ & 4.02 & 0.68 & 80.40 & $\begin{array}{l}\text { Very } \\
\text { good }\end{array}$ \\
\hline 13 & 6 & $\begin{array}{l}\text { Considering helping each other as } \\
\text { moral }\end{array}$ & 4.02 & 0.80 & 80.40 & $\begin{array}{l}\text { Very } \\
\text { good }\end{array}$ \\
\hline 14 & 19 & $\begin{array}{l}\text { Considering parents' rearing and } \\
\text { advice as moral }\end{array}$ & 3.96 & 0.75 & 79.20 & Good \\
\hline 15 & 8 & Considering societal ethos as moral & 3.96 & 0.97 & 79.20 & good \\
\hline 16 & 3 & $\begin{array}{l}\text { Considering friend's opinion as } \\
\text { moral }\end{array}$ & 3.88 & 0.92 & 77.60 & good \\
\hline 17 & 11 & Contravening law is immoral & 3.88 & 0.85 & 77.60 & good \\
\hline 18 & 7 & Avoiding lies as moral & 3.86 & 0.76 & 77.20 & good \\
\hline
\end{tabular}




\begin{tabular}{|c|c|c|c|c|c|c|}
\hline 19 & 28 & $\begin{array}{l}\text { instilling responsibility for societal } \\
\text { progress as moral }\end{array}$ & 3.86 & 0.76 & 77.20 & good \\
\hline 20 & 25 & $\begin{array}{l}\text { Encouraging cooperation as a basis } \\
\text { for progress as moral }\end{array}$ & 3.82 & 0.87 & 76.40 & good \\
\hline 21 & 26 & $\begin{array}{l}\text { Encouraging sacrificing own } \\
\text { interest as moral }\end{array}$ & 3.82 & 0.87 & 76.40 & good \\
\hline 22 & 17 & $\begin{array}{l}\text { Encouraging students to become } \\
\text { great thinkers as moral }\end{array}$ & 3.80 & 0.90 & 76.00 & good \\
\hline 23 & 16 & Pocketing others' things as immoral & 3.78 & 0.79 & 75.60 & good \\
\hline 24 & 23 & Keeping promise as moral & 3.78 & 0.91 & 75.60 & good \\
\hline 25 & 29 & $\begin{array}{l}\text { Treating all people in the same way } \\
\text { as moral }\end{array}$ & 3.74 & 0.90 & 74.80 & good \\
\hline 26 & 18 & $\begin{array}{l}\text { Highlighting that moral standards } \\
\text { do not vary }\end{array}$ & 3.72 & 0.76 & 74.40 & good \\
\hline 27 & 20 & Sustaining social order as moral. & 3.68 & 0.71 & 73.60 & good \\
\hline 28 & 13 & $\begin{array}{l}\text { Infusing the responsibility for } \\
\text { serving society as moral. }\end{array}$ & 3.68 & 1.06 & 73.60 & good \\
\hline 29 & 22 & Considering conscience as moral & 3.64 & 0.96 & 72.80 & good \\
\hline 30 & 21 & $\begin{array}{l}\text { Considering the rules of law as } \\
\text { moral. }\end{array}$ & 3.54 & 0.76 & 70.80 & good \\
\hline \multicolumn{3}{|c|}{ Total impact degree } & 3.95 & 0.36 & 79.00 & good \\
\hline
\end{tabular}

Table 4 displays the impact degree of storytelling in promoting moral consciousness as 'very good' in thirteen items as the percentage of teachers' responses have touched $80 \%$ and more. On top, 'Stimulating Islamic moral standards' came first; thereby entailing significant role of storytelling in this regard. The impact degree was 'good' for seventeen items with 'Instilling 'Holy Qur'an' and 'Prophetic tradition' as sources of Islamic standards' in the lead ranking as second. All in all, the impact degree for the role of storytelling in promoting moral consciousness was perceived by religious education teacher as 'good' students' oral proficiency.

The first research sub-question reads as: Are there any statistically significant differences on teachers' responses that are associated with their gender? A $t$-test was used to find if gender is a tentative factor that may affect teachers' perceptions. This is shown in Table 5 as follows:

Table 5. T-test results of gender as a tentative factor

\begin{tabular}{ccccccc}
\hline \multicolumn{2}{c}{ Male teachers (N. 23) } & \multicolumn{2}{c}{ Female teachers (N. 27) } & \multirow{2}{*}{ s } & \multirow{2}{*}{ significance } \\
Mean & Standard & Mean & Standard & & \\
\hline 3.91 & 0.42 & 3.99 & .31 & .75 & .46 \\
\hline
\end{tabular}

The results in Table 5 indicate that there are no significant statistical differences between the means of the two groups due to the effect of gender as an intervening factor. Specifically, the Table shows $t$ value as .75 which means that 
there were no significant differences at $\mathrm{a}=0.05$ from the teachers' perspectives due to gender.

Regarding the second research sub-question, it reads as: Are there any statistically significant differences on teachers' responses that are associated with their academic qualification? A $t$-test was used to find if teaching experience is a tentative factor that may affect teachers' perceptions. This is shown in Table 6 as follows:

Table 6. T-test results of teaching experience as a tentative factor

\begin{tabular}{|c|c|c|c|c|c|}
\hline \multicolumn{2}{|c|}{$\begin{array}{c}\text { Experience ranging From } 1 \\
\text { to } 5 \text { years } \\
\text { (N. } 3 \text { ) }\end{array}$} & \multicolumn{2}{|c|}{$\begin{array}{c}\text { Experience ranging From } \\
5 \text { to } 10 \text { years and more } \\
\text { (N.47) }\end{array}$} & \multirow[t]{2}{*}{$T$} & \multirow[t]{2}{*}{ significance } \\
\hline M. & S. D & M. & S. D & & \\
\hline 4.71 & .19 & 3.94 & 0.37 & 1.07 & .29 \\
\hline
\end{tabular}

The findings, in Table 6, indicate that there are no significant statistical differences between the means of the two groups due to the effect of teaching experience as an overruling factor. Specifically, the Table shows $t$ value as 1.07 and the significance level as 0.29 which means that there were no significant differences at $\mathrm{a}=0.05$ from the teachers' perspectives due to teaching experience. Concerning the third research sub-question, it reads as: Are there any statistically significant differences on teachers' responses that are associated with their academic qualification? Firstly, Table 7 details the number of teachers in light of their academic qualifications as follows:

Table 7. Details of teachers' academic qualifications

\begin{tabular}{lccc}
\hline $\begin{array}{c}\text { Teachers' academic } \\
\text { qualification }\end{array}$ & Master degree & Bachelor degree & Diploma degree \\
\hline Number of teachers & 9 & 39 & 2 \\
\hline
\end{tabular}

In order to find the effect An ANCOVA test was used to find if teacher's academic qualification is a tentative factor that may affect teachers' perceptions. This is shown in Table 8:

Table 8. ANCOVA results of academic qualifications as a tentative factor

\begin{tabular}{cccccc}
\hline $\begin{array}{c}\text { Source of } \\
\text { variance }\end{array}$ & DF & $\begin{array}{c}\text { Sum of } \\
\text { squares }\end{array}$ & $\begin{array}{c}\text { Mean } \\
\text { square }\end{array}$ & F & significance \\
\hline Between groups & 2 & .155 & .077 & .58 & .56 \\
Within groups & 48 & 6.250 & .133 & .58 & \\
\hline
\end{tabular}

The findings, in Table 8, indicate that there are no significant statistical differences between the means of the two groups due to the effect of teaching experience as an overruling factor. Specifically, the Table shows $F$ value as .58 and the significance value as 0.56 which means that there were no significant 
differences at $\mathrm{a}=0.05$ from the teachers' perspectives due to academic qualification.

\section{Discussion}

The key point in this study was exploring the role of storytelling in promoting moral consciousness among religious education teachers by the means of mapping their opinions by a survey questionnaire. The study reported a 'good' impact of the effectiveness of storytelling.

Generally speaking and considering the world around us, we can see how stories guide the biblical, social, economic, and even the political behaviors. Fortunately, cultures are now grasping the values of stories. Empirically and credibility speaking, the findings of the current study are in congruence with Gottschall (2012) who theorized that stories place individuals with each other round joint values. In consequence, teachers can shape their students' behaviors in a way that meet moral ends. In Gottschall's own words: "a story is, to coin a phrase, the operating system of human consciousness".

An explanation of top scored response (viz. 'Stimulating Islamic moral standards') or of the second ranked response (viz.'Instilling 'Holy Qur'an' and 'Prophetic tradition' as sources of Islamic standards') is in congruence with The Movement of End Violence statements by Richie (2015) highlighted the significant role of storytelling, most startlingly, by the statement that reads:" there's a story behind we started doing this work, a story that connects us, and a story that will bring others along". Here in the present study, the obtained responses reflected how students were able to get along with their religion. To this end, stories were perceived by the participant teachers as powerful tools that raised their students' consciousness.

The findings of the present study are in line with the findings obtained in artificial Intelligence science which takes human consciousness further by testing it on machines by creating simulation programs that have the rhetoric of the story; either by films, TV, games, etc. Stories have the power to inspire and change the behavior of people (O'Neill \& Riedl, 2014).

As it was said, none of the variables of gender, teaching experience or even academic qualification intervene in the effectiveness of delivering storytelling. The study demonstrated a remarkable degree existing in teachers' responses. One effective means of promoting moral consciousness might be the utilization of storytelling; one may conclude. This in congruence with Herman's (1997) who put forth conclusions regarding the nature of storytelling; as it entails guiding, mentoring, counseling, and standing with others. In a way or another, storytelling is about giving advice in an indirect manner. This is in line with Polletta's (2006) definition of a story as "a sequence of events in the order in which they occurred so as to make a normative point". To this end, 'to make a normative point' is what really matters in telling a story rather than the characteristics of the teller. 
The outcomes exposed a significant relationship between the storytelling and morality regardless to the variables of the teachers. Congruently, Bruner (1991) highlighted storytelling as crucial in raising individual's consciousness to morals. Similarly, in old times, Fisher (1984) elaborated on the association between storytelling and reasoning and thinking.

\section{Conclusion}

The present study considered the effects of storytelling in religious education classes in the promotion of moral consciousness. From the investigation of teachers' reactions to the opinion questionnaire, it may be stated that storytelling aids students to raise their consciousness and thereby behaving morally. To this end, desirable code of practice can be introduced in light of real morals of Islam. Hence, the findings of this study inspire the consideration of morality which stem from 'Holy Qur'an' and 'Prophetic tradition' as sources of Islamic standards.

- The conclusion from this study indicated the powerfulness of storytelling in promoting moral consciousness among students.

- The results of study invited the participant teachers to appreciate the prerequisite for students to have all-embracing prospects to hear stories in religious education classes.

- On the theme of consciousness, it is prerequisite and vital for the apt behavior. Between competence (consciousness) and performance (behavior) facets is a balancing and corresponding affiliation. Competence directs performance. Religious competence, of course, and morality are no exception; thereby, individual's behavior can be shaped accordingly.

- Considering the significance of developing moral behavior in societies, effective methods such as 'storytelling' are of great help. Curriculum designers can include storytelling in all subjects' textbooks in a way that directs well-organized moral education in schools.

Researchers are invited to think of 'code of practice' activities with clear guidelines that capitalize the role of storytelling in creating and maintaining morality in schools. Specifically, activities considering the moral values in a sequenced manner are also strongly recommended. The more religious education teachers are acquainted with religion per se, the better they drive and exemplify moral values for students. It is strongly recommended that religious education teachers deliver a written list of suggested stories that correspond to students' age and interest. 


\section{References}

Ableman, P. (2000). The secret of consciousness: How the brain tells 'The story of me' . London: Marion Boyars.

Alavi, H. R. (2007). Al-Ghazāli on moral education. Journal of Moral Education, 36(3), 309-319. doi:10.1080/03057240701552810

Alkaaf, F., \& Al-Bulushi, A. (2017). Tell and write: The effect of storytelling strategy for developing story writing skills among grade seven learners. Open Journal of Modern Linguistics, 7, 119-141. doi:10.4236/ojml.2017.72010

Baker, A., \& Greene, E. (1977). Storytelling: Art and Technique. New York, NY: R. R. Bowker.

Boyatzis, C. J. (2005). Religious and spiritual development in childhood. In R. F. Paloutzian \& C. L. Park (Eds.), Handbook of the psychology of religion and spirituality (pp. 123-143). New York, NY, US: Guilford Press.

Bruner, J. (1991) The narrative construction of reality. Critical Inquiry, 18 (1), 1-22.

Bunanta, M. (2003). Indonesian folktales. Santa Barbra, CA: Connecticut: Libraries Unlimited.

Chowdhury, M. (2016). Emphasizing morals, values, ethics, and character education in science education and science teaching. The Malaysian Online Journal of Educational Science, 4(2), 1-16. Retrieved February 17, 2019 from https:// files.eric.ed.gov/fulltext/EJ1095995.pdf

Fisher, W. R. (1984) Narration as a human communication paradigm: The case of public moral argument. Communication Monographs; 51(1), 1-22. doi:10.1080/03637758409390180

Gottschall, Jonathan (2012). The storytelling animal: Make us human. Boston, NY: Houghton Mifflin Harcourt.

Halstead, J. M. (2007). Islamic values: A distinctive framework for moral education? Journal of Moral Education, 36(3), 283-296. doi:10.1080/03057240701643056

Heintz, M. (2006). Tolerance, conformity and moral relativism: Cases from Moldova. In C. Hann, and the "Civil Religion" Group, The postsocialist religious question: Faith and power in Central Asia and East-Central Europe, (pp. 193-212). Muenster: LIT Verlag.

Herman, J. L. (1997). Trauma and recovery. New York, NY: Basic Books.

Hussain, K. (2007). An Islamic consideration of western moral education: An exploration of the individual. Journal of Moral Education, 36(3), 297-308. doi:10.1080/03057240701552802

Kelley, J. E. (2008). Harmony, empathy, loyalty, and patience in Japanese children's literature. Social Studies, 99(2), 61-70. doi:10.3200/tsss.99.2.61-70

Li, B., Lee-Urban, S., Johnston, G., \& Riedl, M. O. (2013). Story generation with crowdsourced plot graphs. Association for the Advancement of Artificial Intelligence (www.aaai.org). Retrieved January 18, 2019, from https://www.cc.gatech.edu/ riedl/pubs/aaai13.pdf

Molenda, C. F. \& Bhavnagri, N. P. (2009) .Cooperation through movement education and children's literature. Early Childhood Education Journal, 37(2), 153-159. doi:10.1007/s10643-009-0333-0

Nielsen, J. S. (2000, 27 October). The contribution of interfaith dialogue towards a culture of peace. Paper presented at the International Conference on Dialogue of Civilizations, Institute of Islamic Studies, London. Retrieved from http://wcccoe.org/wcc/what/interreligious/cd36-06.html

O'Neill, B. C., \& Riedl, M. O. (2014, July 27-31). Dramatis: A computational model of suspense. Proceedings of the Twenty-Eighth AAAI Conference on Artificial Intelligence.Québec Convention Center, Québec City, Québec, Canada.Association for the Advancement of Artificial Intelligence, pp. 944-950. 
Retrieved from

https://www.aaai.org/ocs/index.php/AAAI/AAAI14/paper/view/8515/852 3

Polletta, F. (2006).It was like a fever: Storytelling in protest and politics. Chicago: University of Chicago.

Putnam, R. D. (2015). Our kids: The American dream in crisis. NY: Simon \& Schuster.

Richie, B. E. (2015). Reimagining the Movement to End Gender Violence: Anti-racism, Prison Abolition, Women of Color Feminisms, and Other Radical Visions of Justice (Transcript), 5 U. Miami Race \& Soc. Just. L. Rev. 257. Retrieved May 11, 2019, from http:// repository.law.miami.edu/umrsjlr/vol5/iss2/6

Rossano, M. J. (2008) The moral faculty: Does religion promote moral expertise? International Journal for the Psychology of Religion, 1 (3), 169-194. doi:10.1080/10508610802115727

Rumbold, B. (2002). Spirituality and palliative care: Social and pastoral perspectives. Melbourne: Oxford University Press.

Setiawati, S. (2017). Using puppet as media to increase the children vocabulary. Jurnal Pendidikan Al-Ishlah, 8(4), 257-269.

Sinnott, J. (2001). Introduction: Special issue on spirituality and adult development, part 1. Journal of Adult Development, 8(4), 199-200.

Smith, C. (1989). From wonder to wisdom: Using stories to help children grow. New York, NY: Penguin Books.

Stan, C. (2001). Teoria educației: Actualitate şi perspective. Cluj-Napoca, Presa Universitară Clujeană.

UNHCR. (2006). The state of the world's refugees. Geneva: The office of United Nations High Commissioner for Refugees.

Varga, I. (1993). Orthodoxy, modernity and post communism. Paper presented at the Religions Sans Frontieres, Rome.

Walter, D. (2016, September 6). Story is, to coin a phrase, the operating system of human consciousness [Blog post]. Retrieved from

https:// damiengwalter.com/2016/09/06/why-story-is-the-most-importantword-of-the-21st-century/

Yoo, S.-Y. (1997). Children's literature for developing good readers and writers in kindergarten. Education, 118(1), 123-129. Retrieved from https://www.questia.com/library/journal/1G1-20381966/children-s-literaturefor-developing-good-readers.

Zeichner, K. M., \& Liston, D. P. (1996). Reflective teaching: An introduction. Mahwah, NJ: L. Erlbaum Associates. 


\section{Appendix:}

\section{Tool}

The role of storytelling in promoting moral consciousness by:

1. Stimulating Religious moral standards

2. Instilling 'Holy Book' and 'Prophetic tradition' as sources of Religious standards

3. Distinguishing between 'standard' and 'opinion'

4. Capitalizing the need for considering morality

5. Realizing that dishonest deeds are irrelevant to mortality

6. Encouraging students to intermingle as moral.

7. Considering freedom of standard norms as immoral

8. Considering illegal deeds as immoral

9. Encouraging students to take part in voluntary acts as being moral

10. Encourages students to earn money effortlessly as immoral

11. Instilling that hurting oneself as immoral

12. Realizing that not doing bad things as moral

13. Considering helping each other as moral

14. Considering parents' rearing and advice as moral

15. Considering societal ethos as moral

16. Considering friend's opinion as moral

17. Contravening law is immoral

18. Avoiding lies as moral

19. instilling responsibility for societal progress as moral

20. Encouraging cooperation as a basis for progress as moral

21. Encouraging sacrificing own interest as moral

22. Encouraging students to become great thinkers as moral

23. Pocketing others' things as immoral

24. Keeping promise as moral

25. Treating all people in the same way as moral

26. Highlighting that moral standards do not vary

27. Sustaining social order as moral.

28. Infusing the responsibility for serving society as moral.

29. Considering conscience as moral

30. Considering the rules of law as moral. 